\title{
Cobalt-Catalyzed [3+2] Cycloaddition of Alkynes with Cyclic Enones
}<smiles>[R]/C=C(/[R])[C@H]1CCCC(=O)C1</smiles>

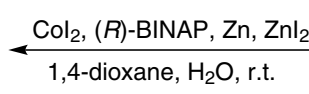
J. Am. Chem. Soc. 2011, 133, 6942<smiles>[R]C#C[C+]</smiles>
$R^{2}$

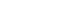

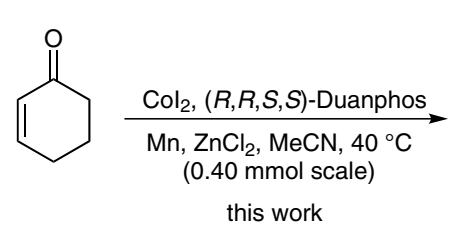

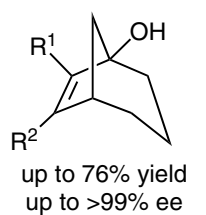

2

\section{Selected examples:}<smiles>OC12CCCC(C1)C(c1ccccc1)=C2c1ccccc1</smiles>

$71 \%$ yield, $90 \%$ ee<smiles>OC12CCC(C1)C(c1ccccc1)=C2c1ccccc1</smiles>

$69 \%$ yield, $78 \%$ ee<smiles>CC1(O)CCCC2CCC1C2c1cccs1</smiles>

$76 \%$ yield, $77 \%$ ee<smiles>CC1(C)CC2(O)CC1C(c1ccccc1)=C2c1ccccc1</smiles>

$54 \%$ yield, $93 \%$ ee

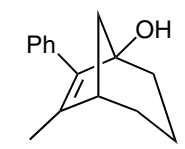

$63 \%$ yield, $90 \%$ ee<smiles>CC1(C)CCC2(O)CC1C(c1ccccc1)=C2c1ccccc1</smiles>

$53 \%$ yield, $>99 \%$ ee

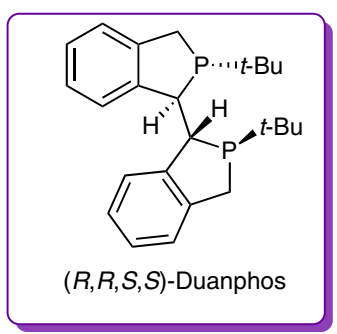

\section{Key words}

cobalt

cycloaddition

tertiary alcohols
Significance: Cheng and co-workers describe a cobalt-catalyzed [3+2]-cycloaddition reaction that provides an atom-economic method for the synthesis of bicyclic tertiary alcohols from alkynes and cyclic enones with regioselectivity. During their previous studies of enantioselective reductive coupling of alkynes with cyclic enones to synthesize $\beta$-substituted ketones $\mathbf{1}$, they found that the use of a $\mathrm{CoBr}_{2} / \mathrm{dppe}-\mathrm{Mn}-\mathrm{ZnCl}_{2}$ system gave the bicyclic product 2 instead in high yield. With the use of a chiral ligand such as Duanphos, moderate to high enantioselectivity was also obtained.
Comment: This reported system is remarkable in that it allows for the reductive cycloaddition of various alkynes and cyclic enones to occur with good regio- and stereoselectivity using an air-stable cobalt catalyst, a mild reducing agent and water as the hydrogen source. Unsymmetrical alkynes also undergo reductive cycloaddition with good to high regioselectivity, though terminal alkynes and silylprotected alkynes were unsuitable. 